\title{
EFFECTS ON THE FINAL INTENSITY OF INPUT FORCES IN LONGBOLTS INSTALLED AT THE MINING OPERATION 2 AREA, OKD, INC.
}

\author{
PAVEL DVoř́́K ${ }^{a, *}$, Eva JirÁnKová ${ }^{b}$ \\ ${ }^{a}$ Minova Bohemia s.r.o., Lihovarská 1199/10, 71600 Ostrava - Radvanice, Czech Republic \\ ${ }^{b}$ VS̆B-Technical University of Ostrava, 17. Listopadu 15/2172, 70833 Ostrava - Poruba, Czech Republic \\ * corresponding author: pavel.dvorak@minovaglobal.com
}

\begin{abstract}
In the deep coal mines of OKD, Inc., both bolts and long bolts of different designs are used for the rock massif and steel arch support reinforcement. Continuous measurement of forces in 6 strand bolts and 1 cable bolt (long bolts, generally) was carried out during the trial operation of the modified Room and pillar mining method at Mining operation 2, site North, OKD, Inc. Hydraulic dynamometers were installed on these long bolts and a monitoring of forces took place throughout the life-time period of the mining panel No. V. From this measurement, a knowledge of their different load behavior with respect to the input stress parameters was obtained. The input intensity of the force applied to the bolting elements is burdened by losses of various kinds. The subject of the article is a description and analysis of the intensity of the initial stressing force applied to individual long bolts (with a threaded clamping bush or wedge barrel) and quantization of short-term stress losses with a description and analysis of these.
\end{abstract}

KEYWORDS: bolting; mining; geotechnics; longbolts; stressing; stressing losses; mine working.

\section{INTRODUCTION}

For the excavation of coal seams in the OstravaKarviná district, the exclusively used mining method is the longwall mining [4. The longwall mining can negatively affect the rock massif and the mining works therein. It is, therefore, necessary to create a protective shaft and stone drift pillars systematically so that these mining effects do not cause damage in the form of unacceptable deformations of galleries or shafts. Protective pillars, however, bind large coal reserves and their subsequent mining is, for a number of reasons, difficult. For the possible removal of these negative phenomena and for the possible mining of remnant pillars, it was decided to prepare the trial operation of the modified Room and Pillar mining method in the protective shaft pillar of the Mining Plant 2, Site North, OKD, Inc. The purpose of the trial operation was to prove the applicability of this mining method under the conditions of the deep coal mines of the Ostrava - Karviná district. The extent of the mining is shown in Figure 1.

This method [13] is characterized by forming retained stable coal pillars where galleries are exclusively driven in rockbolt support. It is precisely the fact that there is no caving of mined out areas that is the most important factor for the protection of the surface, surface objects and main mining workings.

The trial operation started in May 2014 by excavating the panel No. V [4] in the seam No. 30 in the Lower Suchá bed of the Karvina formation. The seam No. 30 was picked out mainly because there is no coal mine burst hazard based on regional prognosis and in an accordance with Decree 659/2004 Coll. [15]. The seam is classified as a seam without a risk of a coal mine burst event, and therefore does not require any active coal mine burst prevention measures.

The seam thickness varies from 2.5 meters up to 5 meters at the point of the connection of the three coal seams No. 30, 31 and 32 with the mining depth of about 850 meters below the surface. The immediate overburden of the 30th seam is formed by a layer of siltstone, followed by a transition of a thick bench of medium-grained sandstone. In the subsequent overburden up to the seam No. 29 sp. l. (648), benches of sandstones and siltstones then alternate. The underlying bed of the coal seam No. 30 is formed by coal seams No. 31 and No 32, along with sandstone benches alternating with siltstone benches. The trial operation was terminated in October 2017 after the finishing of the panel No. II.

The primary objective and function of the installed bolting elements (rock bolts, long bolts) is not only the transfer of shear and tensile loads acting in the massif, but also the ability to bring a certain degree of stress into the massif and thereby positively affect it (closing microcracks, increasing the shear strength). However, it remains a question of how large forces, in combination with the torque of a drilling machine or device, actually act on the bolting element, what will be the intensity of these forces during the process and what factors affect this development of internal forces in the elements. 


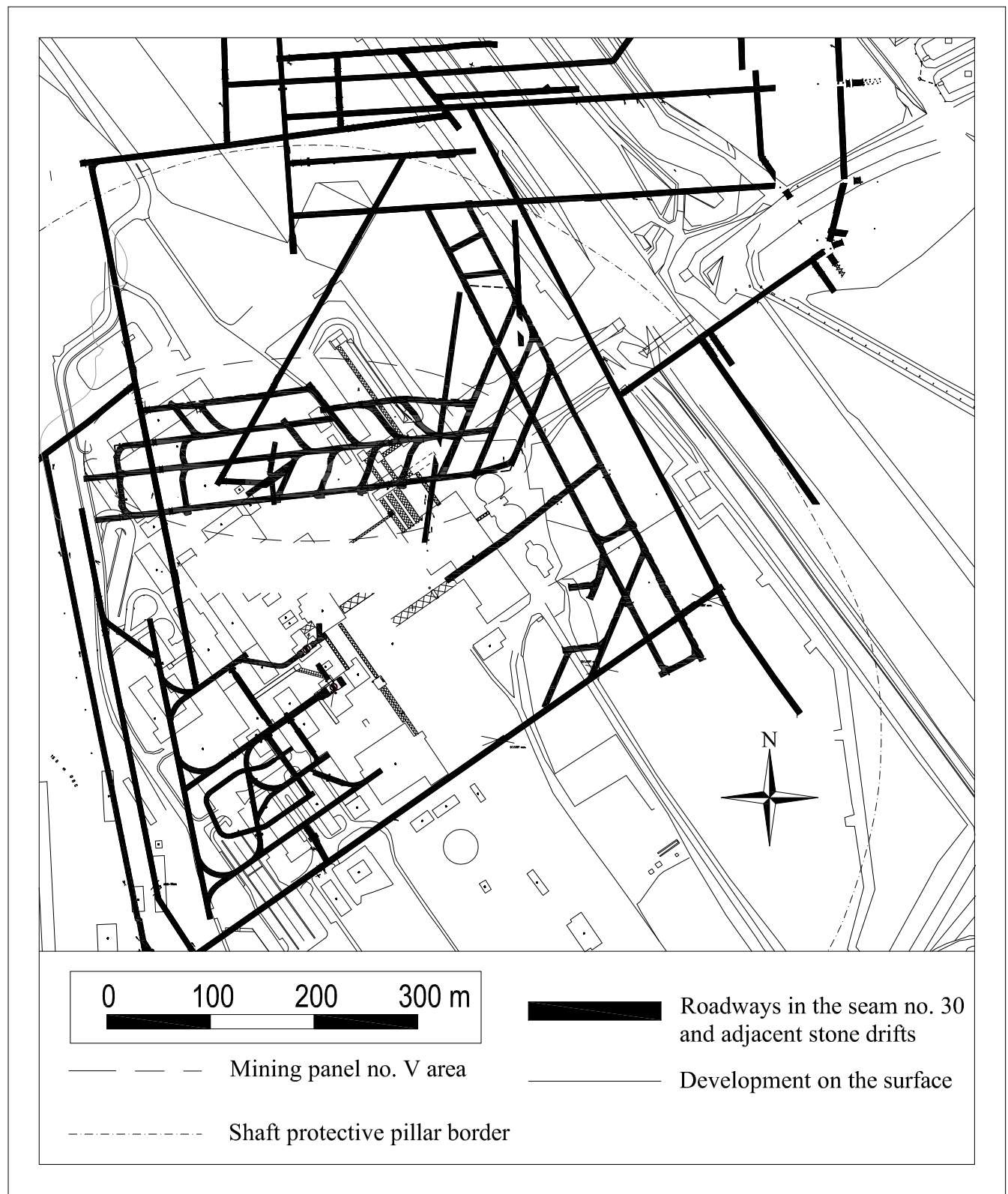

Figure 1. The subject panel No. V as a part of the trial operation of modified mining method Room and Pillar

\section{SuPPORT SYSTEMS AND GOALS OF GEOTECHNICAL MONITORING}

For the purpose of the actual operation and, above all, the long-term stability of a mine supported by long bolts, it was decided to exclusively use resin rebar bolts fully encapsulated along their entire length, where the resin forms not only the bond between the rockbolt and the rock, but also the required protection of the bolt from a corrosion [5]. Based on the calculation, according to the Technical Director's standard No. 2/2012 OKD, a.s. 9], it was decided to use the APB-1k rebar bolts in the project, fully encapsulated along their entire length with polyester adhesive ampoules Lokset and completed with a steel mesh and square shaped washers of a thickness of $8 \mathrm{~mm}$ and dimensions $150 \mathrm{~mm} \times 150 \mathrm{~mm}$. The same rebar bolts were used for the rib reinforcement with the ex- ception of future roadway crossings, where fibreglass bolts were used, mostly the FIB type, or Rockbolt K60-25 Power System washers and nuts in areas with a high horizontal stress. The specific bolt pattern, their number, length and spacing are determined by the geological conditions at the site. There are three variants - a bolting support system for normal conditions, worsened conditions and bad conditions. These variants differ in the number of bolts, their location, time of installation, and possible addition of a 6 meter long IR-6 strand bolt. In some critical situations, e.g., thrust crossings, longer longbolts were used, but this is beyond the scope of this paper.

There were two types of longbolts used, the vast majority was strand bolts IR- 6 and the rest was cable bolts MCA-M. Both types were 6 meters long and bonded at the root with two pieces of Lokset HS Slow 24/800 ampoules (the expected length of the resin 


\begin{tabular}{lccc}
\hline $\begin{array}{c}\text { Bolting } \\
\text { element }\end{array}$ & $\begin{array}{c}\text { Diameter/Cross-sectional } \\
\text { area }\left[\mathrm{mm} / \mathrm{mm}^{2}\right]\end{array}$ & $\begin{array}{c}\text { Maximum load } \\
\text { capacity }[\mathrm{kN}]\end{array}$ & $\begin{array}{c}\text { Length of used } \\
\text { bolting element }[\mathrm{m}]\end{array}$ \\
\hline Rockbolt APB-1k & $21.7 / 370$ & 285 & 2.4 or 2.8 \\
Strandbolt IR-6 & $27 / 308$ & 450 & mostly 6 \\
Cablebolt MCA-M & $21.8 / 312.9$ & 545 & mostly 6 \\
\hline
\end{tabular}

TABLE 1. Features of steel bolts used [6] $[$ ]

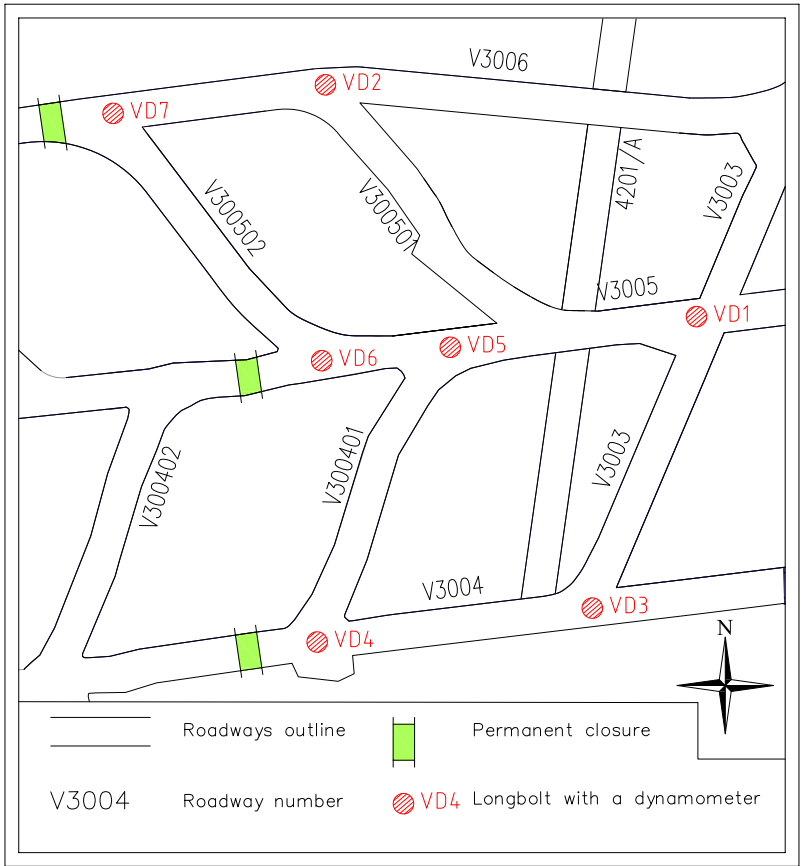

Figure 2. Cutting part of the mining map of the mining panel No. V with the dynamometers shown

bond was 2 metres). The bolts were installed regularly in roadway crossings with a wide span directly in the roof and alternatively in bad geological conditions. The monitoring of the overburden was carried out by tell-tales, strain gauge rock bolts, 3-dimensional CCBM probes [13. Additional measurements of convergence were done at selected locations and hydraulic dynamometers were installed on several long bolts. Dual- or triple height tell-tales were commonly used. Tell-tales were set to height levels 2.2 and 5.2 metres, 2.2 and 5.2 and 7 metres respectively. These altitudes correspond to the used anchor technique, 2.2 metres correspond to the range of the APB- $1 \mathrm{k}$ rockbolts, 5.2 metres corresponds to the width of the corridor and 7 metres are set to determine the dynamics of the movements in the higher overburden, should a longer bolting element be used.

\section{StRESS INPUT AND ITS INTENSITY}

For the anchor element to cooperate properly with the massif, it must be activated. The activation of the element is important for ensuring the proper contact between all involved bolting elements (nut, plate, bolt, masiff) and for the input of the stabilizing force into the massif. This is done in two ways, depending on

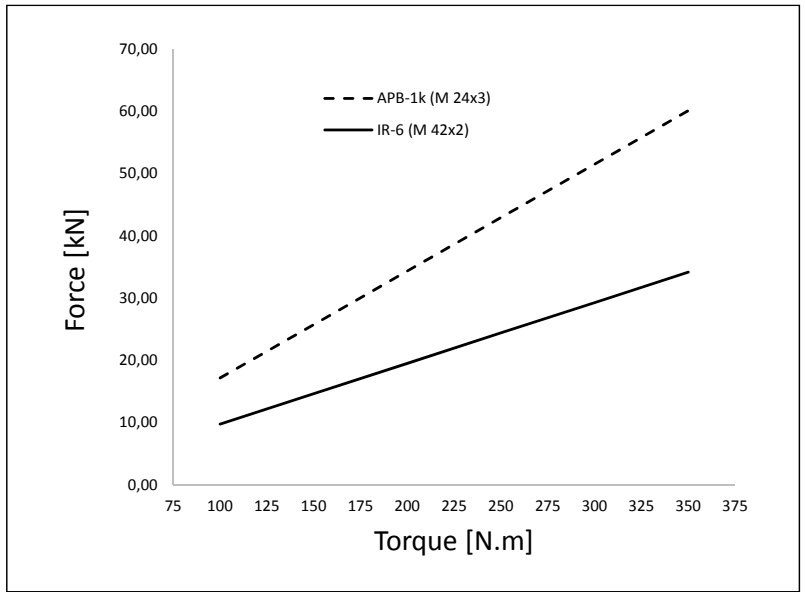

FIgURE 3. Relationship between torque and force in the bolting element 3 .

the design of the bolting element. If the element is provided with a thread or threaded clamp bushing, the activation is performed by tightening the nut on the thread. For elements with a wedge barrel, stressing jacks or other, hydraulic devices are used. The stressing effect affects the rock mass in several ways:

- the compression of the layers reinforces the material of the layers by increasing the shear friction between the individual parts and the material particles;

- the gripping of the thin layers by stressing forces together helps to form a compact, rigid beam that better resists shear deformations;

- stressing helps to close cracks and other discontinuities in the massif, this prevents the migration of liquids and gases, which can have a negative effect on the mechanical properties of both the massive and the support itself.

Dvořák [3] occupied himself with the intensity of the force introduced into a particular bolting element (APB-1k, IR-6) with the threaded part by means of the torque of the drilling and installation equipment.

The greatest effect on the achieved results was the friction between the individual elements (i.e., the friction between the nut, the washer and the threaded rod). It is evident that the magnitude of the force generated in the element is proportional to the magnitude of friction in the thread and between the individual elements. In underground conditions, threads are often heavily clogged with coal dust or corrosion as a 
result of mineralized mine water. This can result in a significant reduction of the input stress. The activation of the bolting elements with the wedge barrel is most often done by means of hydraulic stressing jacks of various designs. The jack is attached to the free end of the cable behind the barrel, the inner clamping jaws are locked on the cable, and the simultaneous combination of the cable pull from the bore and the barrel pressure against the rock causes stress. After releasing the jack, the barrel can preserve the stress in the cablebolt due to its function and, thus, in the massif. The intensity of the input stress is determined by the ability of the jack to develop the tensile force. Here, however, the rule is, the higher the input stress is, the heavier and bigger the stressing jack must be, eg PP-17 (maximum stressing force $170 \mathrm{kN}$, weight $13 \mathrm{~kg}$, Minova), ZPE 23 (230 kN, $23 \mathrm{~kg}$, VSL) or YCW240QX $(240 \mathrm{kN}, 20.5 \mathrm{~kg}$, OVM). In geotechnical or road constructions, the equipment used for stressing of multi-strand anchors can have a weight of several tons and develop a force in the order of dozens of meganewtons [10, 12].

The depth capacity and effect of the induced stress in the rock massif can be simulated in several ways. Numerical modeling or analytical approaches, such as Steinbrenner's and Boussinesque's, can be used. The results of these models [16] show that the relevant depth capacity and the resulting influence of the force is only in the immediate vicinity of its location. With the distance from the perpendicular projection of the point of action and the direction of the depth, the influence of the force decreases rapidly.

\section{Development and efFects on THE RESULTANT INTENSITY OF THE STRESS}

The measurements in the mining panel No. V in the area of the trial operation of the modified Room and Pillar mining method resulted in the intensity of the input stressing force in the 6 IR- 6 strandbolts and 1 MCA-M cablebolt of a $6 \mathrm{~m}$ length, fitted with Glötzl KN500 A5 dynamometers (Figure 2). IR-6 anchors have been installed and activated with air operated, telescopic leg type drilling and bolting Super Turbo Bolter machine. MCA-M cablebolts were stressed by the hydraulic jack PP-17 to the initial intensity of $150 \mathrm{kN}$ immediately after installation. This intensity decreased to $70 \mathrm{kN}$ immediately after releasing the jack.

There is a relatively large variation among the intensity of the input stress of the IR- 6 strand bolts. This is due to several factors, the varying inlet air pressure in the individual workplaces $(2.5-5.5$ bar) (i.e., the lower or higher input torque, machine wear, thread clogging, friction between elements and tightening nut). A completely different situation occurred at the anchor VD-7 (cable bolt MCA-M with an anchor sleeve), where the initial stressing force intensity im-

\begin{tabular}{lcc}
\hline Mark & Type & Real initial force $[\mathrm{kN}]$ \\
\hline VD 1 & IR-6 & 30 \\
VD 2 & IR-6 & 30 \\
VD 3 & IR-6 & 45 \\
VD 4 & IR-6 & 25 \\
VD 5 & IR-6 & 25 \\
VD 6 & IR-6 & 10 \\
VD 7 & MCA-M & 70 \\
\hline
\end{tabular}

TABLE 2. Initial forces in bolts $6 \mathrm{~m}$ long 3 .

mediately dropped from 150 to $70 \mathrm{kN}$ after the release of the stressing jack. This was mainly due to the different construction of the cablebolt head (i.e., the clamp bushing with the nut (IR-6) as opposed to the MCA-M wedge barrel).

Generally, losses of stress in structures are contemplated in Eurocode 2: Design of Concrete Structures [2, 14]. This standard divides short-term prestressing losses based on their origin to losses caused by:

- stress loss due to a friction (curvature and wobble) - the loss incurred due to the friction of the cable on the wall of the injection duct wall depending on their curvature;

- anchorage losses - losses due to a wedge draw-in of the anchorage devices during the operation of the anchoring after the stressing;

- elastic shortening of concrete.

In the following, the relevant types of losses will be discussed in more detail. In this case, the anchorage loss and elastic deformation of the base material. Because the borehole for a long bolt is straight, it is not necessary to evaluate the friction loss.

\subsection{Anchorage Loss}

As it was already mentioned above, an anchorage loss is a loss due to a wedge draw-in back into the barrel after releasing the stressing jack. To reach the final intensity of stress, the wedges must be released from the barrel by the pressure of the jack, and thereby creating a gap between the barrel and wedges. The size of this gap is critical for the resulting value of the anchorage loss (Figure 4).

Some degree of anchorage loss can also occur with coarse threaded rods, the movement of the nut along the thread can reach an order of tenths of milimeters. For fine metric threads, the nut movement is completely negligible.

The anchorage loss [2] is given by the equation

$$
\Delta \sigma_{p w}=\frac{-w E_{p}}{l_{p}}=\frac{-\left(X_{1}-X_{2}\right) E_{p}}{l_{p}}
$$

where $w$ is the anchorage wedge draw-in, $E_{p}$ is the modulus of elasticity of the cablebolt material, $l_{p}$ is the cablebolt free length, $X_{1}, X_{2}$ are the wedge positions 


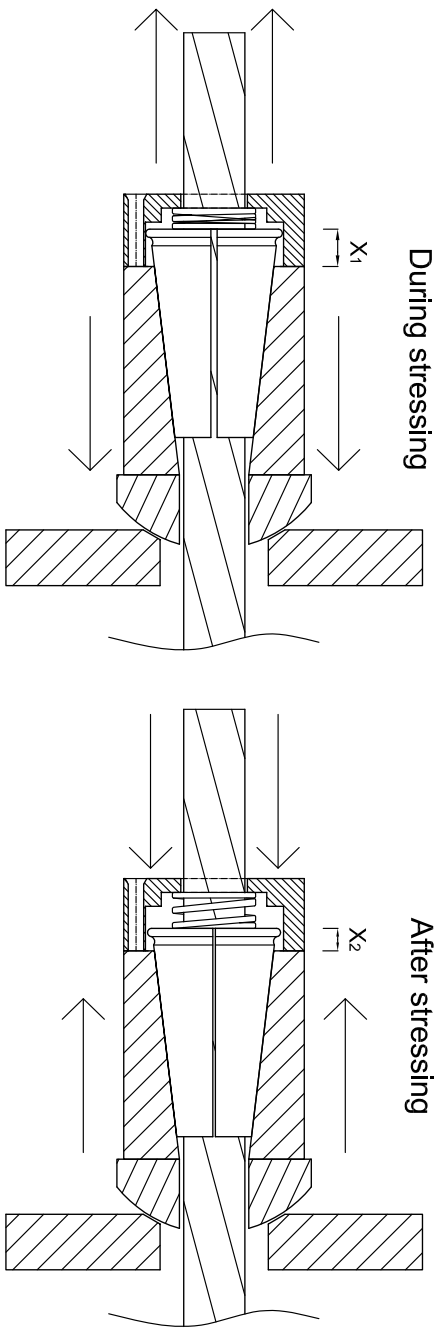

Figure 4. Wedge draw-in mechanism

during the stressing and after releasing the stressing jack (Figure 4).

If we put real values into (1) (i.e., the free lenght of a longbolt, which is 4 metres ( $6 \mathrm{~m}$ without the resin bond), the $3 \mathrm{~mm}$ measured average wedge draw-in and $195 \mathrm{GPa}$ as Young's modulus for spring steel we get $-146.25 \mathrm{MPa}$. That is $-45.76 \mathrm{kN}$ after reducing.

The foreign literature [11] shows anchorage losses of $52 \%$ in the Hi-Ten Bolt system with a similar wedge barrel construction using the pushing springs (i.e., only $48 \%$ of the original stress intensity is retained in the case of an anchorage loss). For strand bolts, due to their fine metric thread M $42 \times 2$, the anchorage loss can be ignored.

\subsection{LOSS OF STRESS DUE TO ELASTIC DEFORMATION OF THE SURROUNDING ROCK}

Stressing leads to compression of the surrounding rock mass. The compression rate corresponds to the rate of the loss. The calculation includes rheological properties of the rock mass. The loss is thus dependent on the instant condition of the rock and its alteration level depending on the amount of time since the be-

\begin{tabular}{lcc}
\hline \multicolumn{1}{c}{ Rock } & $\delta$ & $\alpha$ \\
\hline Claystone & 0.0157 & 0.89338 \\
Siltstone & 0.00947 & 0.87255 \\
Medium-grained sandstone & 0.00713 & 0.63503 \\
Coarse-grained sandstone & 0.04017 & 0.57291 \\
\hline
\end{tabular}

TABLE 3. Rheological coefficients for individual materials [1.

\begin{tabular}{lcc}
\hline & $\begin{array}{c}\text { MCA-M } \\
{[\mathrm{kN}]}\end{array}$ & $\begin{array}{c}\text { IR-6 } \\
{[\mathrm{kN}]}\end{array}$ \\
\hline Initial stressing force & 150 & aver. 30.00 \\
Anchorage loss & -45.76 & $\approx 0$ \\
Elastic deformation loss & -32.45 & -9.34 \\
Total loss & -78.21 & -9.34 \\
Remaining force & 71.79 & 20.66 \\
\hline
\end{tabular}

TABLE 4. Total quantification of losses in longbolts.

ginning of the road-heading works. The loss $\Delta p_{e}$ is calculated according to the following formula [2]:

$$
\psi=\frac{A_{p} E_{p}}{A_{h} E_{h}},
$$

where $\sigma_{p}$ is the residual stress in the element after deducting the present losses $\sum \Delta p$ from the initial intensity of the stress $p_{0}, A_{p}$ is the cross sectional area of the element, $E_{p}$ is the modulus of elasticity of the element, $A_{h}$ is the surface area of the washer, $E_{h}$ is the modulus of elasticity of the rock mass:

$$
\begin{gathered}
\Delta p_{e}=\frac{\sigma_{p} \psi}{1+\psi}, \\
\sigma_{p}=p_{0}-\sum \Delta p .
\end{gathered}
$$

Rock properties can be considered as varying in time, a rock mass may degrade over time due to weathering activities of wind, water, etc. The formula for the auxiliary constant $\psi$ is:

$$
\psi=\frac{A_{p} E_{p}}{A_{h} E_{h(t)}} .
$$

The modulus of elasticity of rock mass in time [1]

$$
\begin{gathered}
\phi=\frac{\delta t^{1-\alpha}}{1-\alpha}, \\
E_{h(t)}=\frac{E}{1+\phi}, \\
\Delta \sigma_{p w}=\frac{-w E_{p}}{l_{p}}=\frac{-\left(X_{1}-X_{2}\right) E_{p}}{l_{p}} .
\end{gathered}
$$

When we put values for siltstone (estimated value for $E=6000 \mathrm{GPa}$ and the area of the washer $150 \mathrm{~mm} \times$ $\left.150 \mathrm{~mm}\left(22500 \mathrm{~mm}^{2}\right)\right)$ into previous equations (6)-(8) and due to the minimal time interval of the excavation from the installation of the longbolts, we do not use the time-dependent parameter of the elastic modulus of the siltstone. We then get the total loss of the cable bolt MCA-M and stran dbolt IR-6, which is shown in Table 4 . 


\section{Conclusions}

In the protective shaft pillar of Mining operation 2, site North, OKD, Inc. from May 2014 until October 2017, the trial operation of the modified mining method Room and Pillar was carried out. The principle of this mining method is to leave stable coal pillars, which will be the permanent support of the overburden. In order to avoid a massive stratification of the overburden, a system of reinforcement of mining works was designed using a rock bolt reinforcement and various types of long bolts (cable bolts, strand bolts). The input intensity of the forces applied to the bolting elements are subjected to losses of various kind. On the basis of the measurements made during the trial operation of the modified Room and Pillar method, the relationship between the intensity of the theoretical and the actual input force in the bolting element was determined. It can be said that on the basis of the in situ measurements and the calculated values, the difference in the input stressing force intensity is obvious. This difference is mainly due to the design of the longbolts and the intensity of the input stressing force. The cablebolts are significantly affected by the anchorage loss depending on the movement of wedges in the barrel body during the stressing. On the contrary, the IR- 6 strand bolts do not suffer from this because of the tightness of the metric thread on the clamp bushing. Losses caused by the deformation of the base material (rock mass) are proportional to the applied stress. These losses, therefore, are lower for the strandbolts. Considering the calculated elastic deformation loss at the strandbolt, it can be assumed that the input stress intensity was still about $10 \mathrm{kN}$ higher than the intensity measured by the dynamometer. In any case, measurements have shown that short-term losses have a significant effect on the intensity of the input force applied to the element and should be considered in the projects. Although practical use of cable bolts is quite common, there is not much research done on the relationship between the theoretical and real input force. The results obtained are of a practical significance not only for the design of the reinforcement of mine workings but also where the stressing of bolting elements is considered (i.e., in geotechnics, civil and transportation engineering and other branches of human activity).

\section{REFERENCES}

[1] Aldorf, J.: 1999, Mechanika podzemních konstrukcí (Mechanics of underground structures). Ostrava: Nakladatelství VŠB-TU Ostrava,410 p, (in Czech).

[2] British Standards Institution: (2008). Eurocode 2: design of concrete structures: British standard. London: BSi.
[3] Dvořák, P.: 2017, Activation of threaded bolting elements. Journal of fundamental and applied sciences, 9, No. 1S, 1-11.

[4] Jiránková, E., Mučková, J., Jadviščok, P., Vochta, R., Molčák, V., Havlicová, M.: 2016, Geodetic Monitoring of the Surface within the Trial Operation of the Room and Pillar Mining Method in the Karvina Part of the OstravaKarvina Coal District. International journal of clean coal and energy, 5, No. 2, 37-44. DOI:10.4236/ijcce.2016.52004

[5] Meikle, T., Tadolini S.C., Sainsbury, B., Bolton, J.: 2016, Laboratory and field testing of bolting systems subjected to highly corrosive environments. International Journal of Mining Science and Technology.No.27, Pages 101-106.

[6] Minova: 2012, Resin bolts type APP, APG, APB. Available on: http://www . arnall.com.pl/app-apg-apb

[7] Minova: 2014, Pramencové svorníky typu IR-6 (Strandbolts IR-6). Minova Bohemia s.r.o., 2014. (In Czech)

[8] Minova: 2012, Lanový svorník MCA-M (Cablebolt MCA-M). Minova Bohemia s.r.o., 2014. (In Czech)

[9] OKD, a.s.: 2012, Technický standard č. 2/2012 technického ředitele OKD, a.s. - Dimenzování samostatné svorníkové výztuže dlouhých důlních děl obdélníkového a lichoběžníkového průřezu v podmínkách OKD (Technical Standard No. 2/2012 of the Technical Director of OKD, a.s. - Dimensioning of rockbolt support of long mine excavations with rectangular and trapezoidal cross-sections in the conditions of OKD, Inc.). OKD, a.s., (in Czech).

[10] OVM: 2010, OVM prestressing systems. Available on http://www.tensindo-ovm.com

[11] Rataj, M.:2008, Development of Hi-Ten bolt in australian coal mines.[online]. Available on: http://www.dsiminingproducts.com

[12] VSL International Ltd:2002, Multistrand post-tensioning. Available on http://www.vsl.net

[13] Waclawik P., Šňupárek R., Kukutsch R.: 2017, Rock bolting at the Room and pillar method at great depths. Procedia Engineering, 191, 575-582. DOI:10.1016/j.proeng.2017.05.220

[14] Zhou, Z., He, J., Chen, G., Ou, J.: 2009, A Smart Steel Strand for the Evaluation of Prestress Loss Distribution in Post-tensioned Concrete Structures. Journal of Intelligent Material Systems and Structures, 20, No. 6, 1901-1912. DOI:10.1177/1045389X09347021

[15] The Czech Repulic. The Czech mining authority in Prague. Regulation (Decree) no.659/2004 on safety and health protection at work and operation safety in mines with the rockbursts risk. (in Czech).

[16] Hulla, J., Turček, P.:2005, Zakládání staveb (Foundation of buildings). Bratislava: Jaga Group, v.o.s., 350 p,Ostrava,410 p, (in Czech). 